\title{
Teknologi Tanaman Padi Sistem Tanam Benih Langsung dengan Hambur di Dataran Tinggi Sumatera Utara (Studi Kasus di Kabupaten Humbang Hasundutan)
}

\author{
Rice Plant Technology with Direct Seed Planting System by Scattering \\ in the Highlands of North Sumatra \\ (Case Study in Humbang Hasundutan Regency)
}

\author{
Imelda S. Marpaung ${ }^{1}$, Tumpal Sipahutar ${ }^{2}$, Deddy R. Siagian ${ }^{3}$, Tommy P. \\ 1,2,3,4 Balai Pengkajian Teknologi Pertanian Sumatera Utara
}

\section{ARTICLE INFO}

Article history:

DOI:

$\underline{10.30595 / p s p f s . v 2 i .209}$

Submitted:

July 29, 2021

Accepted:

Sept 10, 2021

Published:

Nov 10, 2021

Keywords:

Highlands, Rice, Scattering System

\begin{abstract}
Rice farmers in Humbang Hasundutan Regency still maintain rice technology with the scattering system because farmers feel this planting system to be still relevant to the condition of available resources in Humbang Hasundutan Regency. The study of direct seed planting system technology in Humbang Hasundutan Regency was carried out using a survey method by conducting interviews with key informants in Polung Subdistrict, Humbang Hasundutan Regency. From the interview results, it was found that the transplanting system technology, both with tiles and jajar legowo in Humbang Hasundutan Regency, did not give significantly different results compared to the scattering system. The results of the farming analysis obtained show that the scattering system gives an R/C value of 1.88 compared to the transplanting system of $1.94 \mathrm{R} / \mathrm{C}$.
\end{abstract}

This work is licensed under a Creative Commons Attribution 4.0 International License.

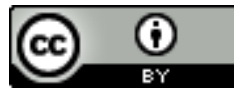

Corresponding Author:

Imelda S. Marpaung

Balai Pengkajian Teknologi Pertanian Sumatera Utara

Email: imelda.bptpsumut@gmail.com

\section{PENDAHULUAN}

Tanaman padi (Oryza sativa L.) merupakan tanaman pangan penting yang telah menjadi makanan pokok lebih dari setengah penduduk dunia. Di Indonesia, padi merupakan komoditas utama dalam menyokong pangan masyarakat. Ketahanan, kemandirian, dan kedaulatan pangan Indonesia dinilai belum kokoh. Hal ini diindikasikan oleh tingginya impor produk pangan. Hingga tahun 2013 masalah ketahanan pangan khususnya beras menjadi persoalan besar bangsa Indonesia. Pada tahun 2011, impornya 1,6 juta ton dan pada tahun 2012 impor beras 1,9 juta ton (Pujiasmanto, 2013).

Kendala dan tantangan yang dihadapi dalam mewujudkan ketahanan pangan nasional adalah kompetisi dalam pemanfaatan sumberdaya lahan dan air. Konversi lahan pertanian untuk kegiatan non pertanian terutama di Jawa menyebabkan produksi pertanian semakin sempit. Dalam hal ini, sektor pertanian menghadapi tantangan untuk meningkatkan efisiensi dan optimalisasi pemanfaatan sumber daya lahan.

Upaya peningkatan produktivitas lahan sawah untuk tanaman padi selalu dilakukan pemerintah baik berupa bantuan permodalan usahatani padi. Percepatan pertanaman padi selalu menjadi kendala karena keterbatasan tenaga, benih dan kersediaan air. Salah satu yang pemecahan masalah untuk mengejar percepatan 
tanam ini adalah dengan pemberian bantuan benih dan alat tanam oleh pemerintah namun ini juga belum mampu untuk mengejar tanam serentak. Selain itu alat tanam juga tidak dapat mengatasi sistem pertanian di lahan yang berlereng sehingga petani masih tetap melakukan pertanaman dengan persemaian sistem konvensional.

Budidaya tanaman padi secara konvensional yang memerlukan persemaian, di beberapa Negara yang memiliki tenaga kerja yang langka biaya penyemaian dan penanaman padi masih dirasakan mahal. Di Kamboja biaya penyemaian dan penanaman berkisar 10-30\% dari biaya produksi (Pandey dan Velasco 2002; Rickman et al. 2001), di Malaysia (71\%), Filipina (42\%) dan Thailand (34\%). (Pandey dan Velasco. 2002). Biaya penyemaian padi di Indonesia saat ini masih tinggi. Di Sumatera Utara biaya penyemaian dan penanaman padi berkisar Rp 55.000/400m2 atau sekitar Rp.1.375.000,-/ha dan dengan borongan alat tanam (transplanter) berkisar Rp 1.200.000,- per ha. Biaya penyemaian dan penanaman ini akan mempengaruhi ongkos produksi tanaman padi.

Cara budi daya padi terbaik mempertimbangkan secara ilmiah aspek lingkungan (tanah, air, iklim, organisme pengganggu tanaman/OPT), karakter tanaman (varietas sesuai) termasuk bentuk tajuk tanaman (Sutoro dan Makarim, 1997), teknologi, dan pengelolaannya, selain aspek sosial dan ekonomi yang turut menentukan kelayakan penerapan teknologi budi daya.

Teknologi sistem tanam menjadi salah satu kebutuhan dalam program intensifikasi petanian tanaman pangan khususnya padi.Pengaturan jarak tanam dalam satu barisan tanaman dalam satuan lahan mempunyai pengaruh langsung terhadap hasil panen (Rasool, et al., 2012; Islam et al., 2012; Maradpour, et al., 2013; Tyeb, et al., 2013). Bozorgi et al., (2011) menyatakan tanaman banyak bergantung pada temperature,radiasi nmatahari, kelembaban, kesuburan tanah untuk pertumbuhan dan pemenuhan nutrisi. Sehingga kepadatan populasi yang terlalu tinggi bisa menjadi masalah pembatas tanaman untuk menggunakan komponen tersebut. Salah satu inovasi teknologi yang dilakukan petani diwilayah yang kekurangan tenaga kerja adalah penanaman benih langsung (tabela) dengan cara menghambur (direct seeding). Teknologi ini sudah dilakukan petani sejak tahun 2000 namun saat ini mulai ditinggalkan oleh petani dengan adanya sistem tanam yang baru yang setiap tahunnya inovasi sistim tanam padi terus mengalami perbaikan. Namun teknologi tanam benih langsung tetap dilakukan oleh petani di kabupaten Humbang Hasundutan Propinsi Sumatera Utara hal ini menunjukkan teknologi ini masih relevan dilakukan oleh petani.

\section{METODE PENELITIAN}

Kegiatan dilakukan dengan metode survey di Kecamatan Polung Kabupaten Humbang Hasundutan Provinsi Sumatera Utara pada bulan Maret 2019. Lokasi kegiatan memiliki agroekosistem lahan sawah dataran tinggi. Kabupaten Humbang Hasundutan berada di bagian tengah wilayah Provinsi Sumatera Utara, yang terletak pada garis $02^{\circ} 01^{\prime}-2^{\circ} 28^{\prime}$ Lintang Utara dan $98^{\circ} 10^{\prime}-98^{\circ} 58^{\prime}$ Bujur Timur.

Penentuan sampel dalam penelitian ini adalah menggunakan nonprobability sampling dengan teknik pengambilan sampling convenience sampling dengan memilih sampel secara sengaja sesuai dengan keinginan peneliti dengan pertimbangan-pertimbangan khusus (Kuncoro. M, 2009). Data dikumpulkan dari petani yang masih menerapkan budidaya padi sistim hambur dan petani yang menerapkan sistim tapin. sebanyak 20 petani. Selain itu data dikumpulkan meliputi data sekunder berupa luas pertanaman padi di tingkat kabupaten dan tingkat kecamatan di Kabupaten Humbang Hasundutan serta produktifitas tanaman padi dengan cara tanam sistem tanam pindah dan sistem hambur. Data dari lapangan ditabulasi, kemudian dirata-ratakan, dianalisis secara deskriptif. Analisis usahatani yang dihitung yaitu penerimaan dan pendapatan. Pendapatan merupakan selisih antara penerimaan dengan biaya yang dikeluarkan (Soekartawi, 1995). Untuk mengetahui usahatani menguntungkan atau tidak secara ekonomi dapat dianalisa dengan menggunakan nisbah atau perbandingan antara penerimaan dengan biaya (Revenue cost ratio) yang dirumuskan dengan :

$$
\mathrm{R} / \mathrm{C}=\mathrm{PT} / \mathrm{BT}
$$

dimana:

$\mathrm{R} / \mathrm{C}$ :Nisbah penerimaan dan biaya

$\mathrm{PT}$ : Penerimaan total (Rp)

BT : Biaya total (Rp)

Kriteria R/C > 1 maka usahatani mengalami keuntungan karena penerimaan lebih besar dari biaya, $\mathrm{R} / \mathrm{C}<1$ maka usahatani mengalami kerugian karena penerimaan lebih kecil.

\section{HASIL DAN PEMBAHASAN \\ Karakteristik Lokasi}

Kabupaten Humbang Hasundutan yang sering disebut Humbahas atau Humbanghas terletak di barisan Pegunungan Bukit Barisan, Sumatera Utara dengan iklim sejuk mendekati dingin. Kabupaten ini terkenal penghasil Kopi Lintong yang terkenal di dunia. Kabupaten ini hasil pemekaran dari Kabupaten Tapanuli Utara. 
Ibu kota Kabupaten Humbang Hasundutan berada di Dolok Sanggul dengan batas-batas Kabupaten yaitu disebelah Utara berbatasan dengan Kabupaten Samosir, di sebelah Timur dengan Kabupaten Tapanuli Utara, sebelah Selatan berbatasan dengan Kabupaten Tapanuli Tengah dan di sebelah Barat berbatasan dengan Kabupaten Pakpak Barat.

Luas Kabupaten Humbang Hasundutan berkisar 244.059,97 Ha atau sama dengan 244,059 $\mathrm{km}^{2}$. Kabupaten Humbang Hasundutan terdiri dari 10 kecamatan dimana Kecamatan Parlilitan, Pakkat dan Kecamatan Polung merupakan 3 (tiga) kecamatan terluas dengan masing-masing luasnya adalah $71.011 .43 \mathrm{Ha}$ $(29.10 \%), 37.721 .54 \mathrm{Ha}(15.46 \%)$ dan $29.040 .35 \mathrm{Ha}(11.90 \%)$. Sedangkan wilayah dengan luas terkecil adalah Kecamatan Baktiraja, Paranginan dan Kecamatan Lintong Nihuta dengan luasan masing-masing adalah $2.151,63 \mathrm{Ha}(0.88 \%), 4.939,2(2.02 \%)$ dan $13.493,86 \mathrm{Ha}(5.53 \%)$.

Tabel 1. Kecamatan di Kabupaten Humbang Hasundutan dan luasannya

\begin{tabular}{lcc}
\hline \multicolumn{1}{c}{ Kecamatan } & Luas (Hektare) & Luas (\%) \\
\hline Kec. Baktiraja & 2.151 .63 & 0.88 \\
Kec. Doloksanggul & 21.851 .08 & 8.95 \\
Kec. Lintong Nihuta & 13.493 .86 & 5.53 \\
Kec. Onanganjang & 21.662 .69 & 8.88 \\
Kec. Pakkat & 37.721 .54 & 15.46 \\
Kec. Paranginan & 4.939 .20 & 2.02 \\
Kec. Parlilitan & 71.011 .43 & 29.10 \\
Kec. Pollung & 29.040 .35 & 11.90 \\
Kec. Sijamapolang & 15.725 .35 & 6.44 \\
Kec. Tarabintang & 26.462 .84 & 10.84 \\
\hline \multicolumn{1}{c}{ TOTAL } & $\mathbf{2 4 4 . 0 5 9 . 9 7}$ & $\mathbf{1 0 0 . 0 0}$ \\
\hline
\end{tabular}

Sumber: Kabupaten Humbang Hasundutan dalam Angka, 2014

Kabupaten Humbang Hasundutan yang terletak dekat dengan garis khatulistiwa membuat provinsi ini tergolong kedalam daerah beriklim tropis basah seperti kabupaten lainnya di Provinsi Sumatera Utara, kabupaten ini mempunyai 2 musim, yakni musim kemarau dan musim penghujan. Musim kemarau biasanya terjadi pada bulan April sampai dengan bulan Agustus dan musim penghujan terjadi pada bulan September sampai dengan Maret, diantara kedua musim ini terdapat musim pancaroba. Keadaan iklim Kabupaten Humbang Hasundutan dipengaruhi oleh Samudera Indonesia. Suhu udara rata-rata $17^{\circ} \mathrm{C}-29^{\circ} \mathrm{C}$ per bulan dengan rata-rata kelembaban udara $85,94 \%$.

Pada tahun 2018 rata-rata curah hujan mencapai $247.18 \mathrm{~mm}$ per bulan dengan banyaknya hari hujan mencapai 220.4 hari setahun atau rata-rata 18.4 hari per bulan. Curah hujan yang paling besar terjadi pada bulan November yaitu $419 . .87 \mathrm{~mm}$ dengan banyaknya hari hujan mencapai 25.7 hari. Curah hujan yang paling rendah terjadi pada Bulan Juni yaitu 109.40 mm dengan hari hujan sebanyak 11.5 hari (Tabel 2).

Kabupaten Humbang Hasundutan memiliki ketinggian $0-2.000$ meter diatas permukaan laut dan secara spasial dibagi menjadi 3 kelas, yakni: Kelas I (0-700 mdpl), seluas 185.614,63 Ha dan Kelas II (700-1.200 mdpl), seluas 183.487,80 Ha, dan kelas III (1.200-2000mdpl), seluas 89.391,59 Ha. Kabupaten Humbang Hasundutan memiliki kemiringan lereng $0-75 \%$ dan secara spasial dibagi menjadi 4 kelas, yakni: Kelas I (0-8 \%), seluas 238.992,97 Ha; Kelas II (8-15 \%), seluas 59.414,98 Ha; Kelas III (15-40 \%), seluas 27.900,12 Ha; dan Kelas IV (40-75 \%), seluas 132.185,95 H. Berdasarkan hal tersebut maka pertanian di Kabupaten Humbahas diarahkan pada lahan yang memiliki kemiringan/berlereng dan di dataran tinggi. Untuk pengembangan komoditas padi juga memerlukan teknologi budidaya yang disesuaikan untuk dataran tinggi dan berlereng.

Tabel 2. Rata-rata Jumlah Hujan dan Curah Hujan Setiap Bulan di Kabupaten Humbang Hasundutan

\begin{tabular}{lcc}
\hline Bulan & $\begin{array}{c}\text { Banyaknya hari hujan } \\
\text { (hari) }\end{array}$ & Curah hujan(mm) \\
\hline Januari & 15.0 & 154.75 \\
Februari & 17.1 & 266.00 \\
\hline
\end{tabular}

Proceedings homepage: https://conferenceproceedings.ump.ac.id/index.php/pspfs/issue/view/9 


\begin{tabular}{lcc}
\hline Maret & 19.9 & 309.95 \\
April & 20.8 & 308.55 \\
Mei & 20.4 & 224.60 \\
Juni & 11.5 & 109.40 \\
Juli & 12.3 & 164.15 \\
Agustus & 18.8 & 167.60 \\
September & 20.0 & 237.85 \\
Oktober & 14.3 & 203.05 \\
November & 25.7 & 419.87 \\
Desember & 24.4 & 400.40 \\
\hline Jumlah & $\mathbf{2 2 0 . 4}$ & $\mathbf{2 9 6 6 . 1 7}$ \\
Rata-rata & $\mathbf{1 8 . 4}$ & $\mathbf{2 4 7 . 1 8}$ \\
\hline
\end{tabular}

Sumber: https://humbanghasundutankab.bps.go.id/

\section{Sistem Tanam Benih Langsung}

Ketersediaan sumber daya merupakan salah satu faktor terpenting yang mempengaruhi usahatani padi. Pendekatan ganda sangat penting dilakukan, pertama memperkirakan sumber daya air irigasi yang tersedia untuk mengembangkan pertanian padi irigasi berkelanjutan, dan kedua untuk meningkatkan produktivitas pertanian tadah hujan. Dalam kedua kasus, pertanian padi kemungkinan berada di bawah kondisi air yang berbeda; dalam produksi padi irigasi, kedalaman air dapat dikontrol baik dangkal atau dalam tergantung pada ketersediaan air dan waktu yang dihabiskan untuk pengelolaan air sedangkan produksi padi tadah hujan, tanaman padi akan mengalami berbagai tingkat kekurangan air bahkan sampai kekeringan parah yang mempengaruhi pertanaman padi.

Kendala air yang paling sering di alami petani pada saat penanaman antara lain pada saat benih padi di pindahtanamkan ke lahan kondisi air kurang tersedia sehingga benih mengalami kekeringan dan mati. Selain itu pada lahan sawah tadah hujan maupun lahan rawa kondisi kekurangan air dan kelebihan air menyebabkan petani menunda memindahkan benih yang seharusnya sudah waktunya ditanam sehingga benih ketuaan di persemaian.

Penanaman padi dengan metode konvensional yaitu membesarkan padi di persemaian dan memindahtanamkan benih berumur 15-30 hari di lahan berlumpur dan tergenang (Ehsanullah et al., 2007). Metode ini tidak hanya secara efektif menekan gulma dengan mencegah cahaya untuk mencapai gulma melalui lapisan genangan air, juga memberikan lingkungan tumbuh yang baik bagi tanaman (Rao et al., 2007; Begum et al., 2006; Chauhan dan Johnson, 2009; Farooq et al., 2011). Metode konvensional memerlukan tenaga kerja dan air yang sangat besar untuk menanam padi (Bouman et al., 2007; Bhushan et al., 2007).

Persemaian langsung atau yang dikenal dengan sistem tanam benih langsung merupakan pilihan alternatif untuk mengatasi masalah air dan kelangkaan tenaga kerja pada penanaman padi konvensional, (Weerakoon et al., 2011). Pada sistem usaha tani padi intensif dengan tenaga kerja banyak tersedia dan murah, sistem tanam pindah (tapin) umum dilakukan petani. Pada saat langkanya tenaga kerja sering menyebabkan waktu tanam terlambat, sehingga petani terpaksa menanam bibit padi yang sudah tua sehingga hasil panen rendah. Namun, di daerah dengan tenaga kerja sukar dan mahal sementara harga mesin tanam pindah tidak terjangkau petani, sistem tanam benih langsung (tabela) dapat menjadi alternatif bagi petani.

\section{Trend Sistem Tanam Padi yang Diterapkan di Indonesia}

Indonesia memiliki luas wilayah yang cukup luas namun pada tahun 1979, Indonesia justru menjadi negara pengimpor beras terbesar di dunia. Hal ini menunjukkan bahwa Indonesia kekurangan produksi beras sehingga kebutuhan pangan masyarakat belum dapat terpenuhi dengan baik. Pemerintah melakukan berbagai upaya untuk dapat memenuhi kebutuhan pangan masyarakat dengan meningkatkan produksi padi. Beberapa kebijakan dilakukan mulai dari program swasembada pangan sampai kepada program mewujudkan pertanian modern.

Sejak di mulainya upaya swasembada padi oleh pemerintah sistem tanaman padi yang dikembangkan juga mengalami perubahan. Sistem tanam yang pertama sekali dikenalkan dalam program pembangunan pertanian tanaman padi dalam rangka swasembada pangan mulai tanam tegel, sistem tanam langsung, sistem jajar legowo yang saat ini sedang dimasalkan penggunaannya kepada petani. Sistem tanam padi sawah sampai saat ini umumnya dilakukan petani menggunakan sistem tanam pindah (tapin). Sistem ini selain tidak banyak membutuhkan persyaratan khusus juga tidak banyak resiko. Namun, masih banyak petani yang menggunakan bibit dengan jumlah bibit yang relatif banyak (7-10 batang per rumpun, bahkan lebih dari 10 batang per 
rumpun). Padahal rekomendasi yang umum untuk penggunaan jumlah bibit padi sawah adalah 3 batang per rumpun. Bahkan pada teknologi SRI (The System of Rice Intensification), jumlah bibit yang diterapkan adalah satu batang per rumpun (Kasim, 2004).

Namun di beberapa wilayah yang memiliki kekurangan tenaga kerja pada saat tanam petani banyak menggunakan sistem tanam benih langsung dengan cara dihambur. Tujuan sistem tanam benih langsung untuk mengurangi penggunaan tenaga kerja yang terkonsentrasi pada waktu yang bersamaan seperti pengolahan tanah dan tanam, serta untuk menghindari pembuatan dan pemeliharaan persemaian,efisiensi tenaga kerja tersebut dapat menekan biaya tenaga kerja yang mahal serta mengejar masa tanam yang serempak dengan biaya relatif murah. Penelitian IRRI (1989) menunjukkan sistem tabela telah mengantisipasi kelangkaan tenaga kerja yang terjadi pada tahun 2000-an serta perkembangan teknologi pengendalian gulma yang semakin maju pada waktu itu dan sistem tabela diharapkan semakin populer di Asia khususnya pada sistem usaha tani padi intensif.

Masing-masing sistem tanam memiliki kelebihan diantaranya sistem tanam benih langsung mengefisienkan umur tanaman karena tidak melakukan persemaian, hemat tenaga kerja dan tanaman tidak mengalami stress saat dipindah sedangkan metode sistem tanam pindah memiliki kelebihan antara lain pertumbuhan tanaman lebih seragam, mengurangi serangan organisme penggangu tanaman(gulma, hama dan penyakit) karena tanaman lebih seragam dan teratur tumbuhnya, mengurangi persaingan antar tanaman. Sistem tanam pindah biasa digunakan dengan tegel ataupun jajar legowo. Sistem tanam padi sistem tegel dengan jarak $20 \mathrm{~cm} \times 20 \mathrm{~cm}$ atau lebih rapat lagi. Saat ini telah dikembangkan sistem penanaman yang baru yaitu sistem jajar legowo. Menurut Pahruddin (2004), jajar legowo merupakan perubahan teknologi jarak tanam padi yang dikembangkan dari sistem tanam tegel yang telah berkembang di masyarakat. Prinsip dari sistem tanam jajar legowo adalah pemberian kondisi pada setiap barisan tanam padi untuk mengalami pengaruh sebagai tanaman pinggir.

Teknologi sistem tanam langsung ini sudah banyak dilakukan dibeberapa Negara penghasil padi termasuk Indonesia. Dengan sistem tanam ini penyemaian padi tidak dilakukan. Kendala sistem tanam langsung adalah adanya persaingan tanaman dengan gulma pada saat awal pertumbuhan. Peningkatan jumlah benih padi tanam benih langsung membantu menekan pertumbuhan gulma namum populasi yang tidak sesuai menyebabkan keterbatasan dalam ketersediaan faktor produksi secara maksimum yang berdampak ke hasil panen. Kerapatan tanam berdampak signifikan terhadap hasil dan komponen hasil padi. (Azmi et al., 2000; Baloch et al., 2002; Zhao et al., 2007).

Penyemaian tanam benih langsung dilakukan di beberapa negara tropis seperti Thailand, Malaysia, Filipina dan kamboja (Dawe 2005; Pandey dan Velasco 2002. Inovasi teknologi yang mengalokasikan lebih sedikit input tenaga kerja untuk produksi padi menjadi peluang pertanian kedepannya. Sistem tanam langsung saat ini juga sudah banyak dilakukan dengan memanfaatkan alat mekanisasi dengan penggunaan alat tanam benih langsung yang manual maupun menggunakan tenaga traktor.

Mekanisasi pertanian akan menjadi salah satu kemungkinan untuk teknologi hemat tenaga kerja, seperti traktor tangan untuk persiapan lahan dan mesin perontok, serta pemanen yang dijalankan secara korporasi, telah semakin banyak diadopsi di kalangan petani di Thailand (Bakker et al., 2002). Pemanfaatan alat tanam saat ini banyak yang tidak diadopsi oleh petani disebabkan keterbatasan wilayah sehingga operasional alat tanam tidak dapat dilakukan oleh petani sehingga cara alternatif adalah dengan sebagian beralih dari penanaman tradisional ke penyemaian langsung yang lebih hemat tenaga kerja untuk produksi padi.

\section{Teknologi Eksisting dan Sistem Tanam Benih Langsung Di Kabupaten Humbang Hasundutan}

Kabupaten Humbang Hasundutan dengan agroekositemnya dataran tinggi memiliki keterbatasan adaptasi benih introduksi yang umumnya dihasilkan oleh pemulia di dataran rendah. Beberapa varietas unggul baru yang dihasilkan dan diintroduksikan di kabupaten Humbanghasundutan hanya dapat memberikan produktivitas baik pada ketinggian dibawah $1000 \mathrm{mdpl}$, sehingga sampai saat ini banyak petani masih menggunakan varietas lokal terutama diwilayah dengan ketinggian $1200 \mathrm{mdpl}$. Beberapa varietas tersebut antara lain yang sampai saat ini masih diminati petani karena memiliki keunggulan dari varietas unggul baru diantaranya: Simedan, Sirias, Sipendek, Sihaminjon, Sipisang, Sitambagogo, Sikalimantan, Siansium, Sikaban, Sidarang, Sibelawan, Siboru sonang, Siboru Simbolon, Sibirong, Sigendat, Simendet, Siramos, Sitalibolon, Sitambatua, Sitobu, Sisior, Sijarum, Sigiragira, Sikumpul, Sipote, Sikedeng, Silanting, Sipulut, Sijanggut, Sipagul, Sibalatan, Sihodong, Sipulut birong, Sibogas, Siarang.

Keunggulan varietas lokal tersebut antara lain: efisien pupuk, lebih tahan cekaman, gabah padi dapat disimpan bertahun dan tahan terhadap hama gudang. Kondisi petani yang umumnya menyimpan padinya selama setahun untuk kebutuhan rumahtangganya sangat memerlukan varietas padi yang tahan simpan sangat berbeda dengan varietas unggul yang sudah pernah dicoba oleh petani, sehingga petani menanam varietas unggul bila mereka langsung jual ke pasar namun untuk kebutuhan rumah tangga petani masih menanam varietas lokal meskipun varietas lokal memiliki kelemahan umur panen yang lebih panjang dibanding varietas unggul baru. Varietas unggul baru yang saat ini sudah beradaptasi di kabupaten humbangasundutan pada

Proceedings homepage: https://conferenceproceedings.ump.ac.id/index.php/pspfs/issue/view/9 
ketinggian diatas 1000mdpl seperti sibandung yang diambil dari pertanaman padi di kecamatan baktiraja dengan ketinggian 800 mdpl.

Petani di kabupaten humbanghasundutan menerapkan beberapa cara tanam antara lain sistim hambur, sistim semai dengan cara tanam sistim tegel dan terbaru yang dilakukan petani dengan sistim jajar legowo. Sampai saat ini sistim hambur masih dilakukan oleh hampir $80 \%$ petani di kecamatan pollung yang memiliki ketinggian tempat di atas $1200 \mathrm{mdpl}$. Beberapa alasan yang menyebabkan petani masih menerapkan teknologi sistim tabur antara lain: 1) Belum terlalu ada perbedaan hasil yang signifikan antara sistim tabur dengan cara tanam pindah. 2) Tenaga kerja dan waktu yang diperlukan saat tanam lebih sedikit dibanding dengan sistim tanam pindah. 3) Faktor lingkungan seperti lahan yang berlereng sehingga untuk mengejar musim tanam lebih cepat dengan di hambur. Komponen teknologi padi yang diterapkan oleh petani di Kabupaten Humbang Hasundutan seperti tabel3.

Tabel 3. Komponen Teknologi padi di Kecamatan Polung Kabupaten Humbang Hasundutan

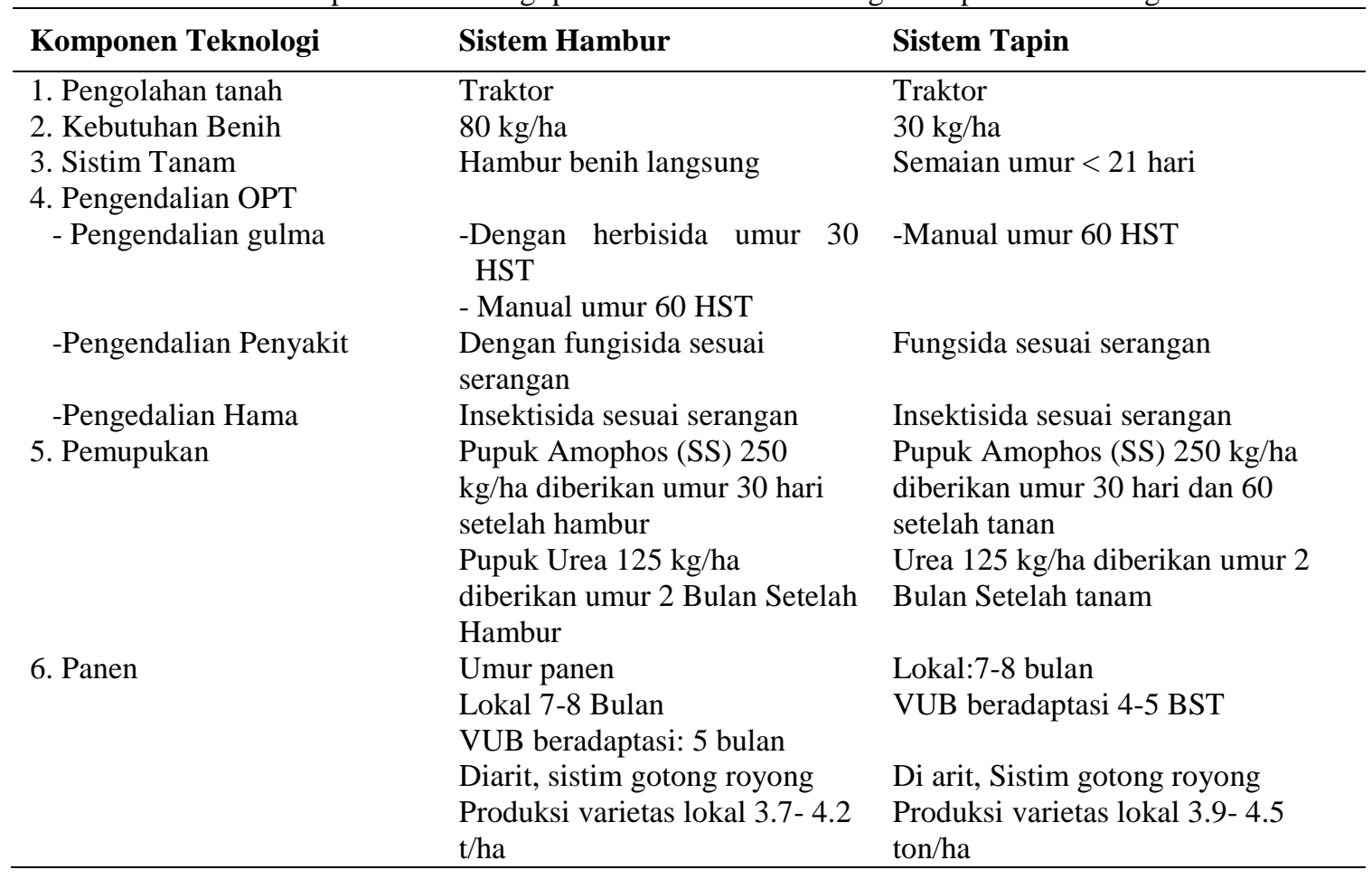

Analisa Usahatani Padi Sistem Hambur di Kabupaten Humbang Hasundutan

Berdasarkan pengamatan dan hasil survey dilapangan menunjukan sebagian besar petani masih mengusahakan usahatani padi hanya satu kali setahun dan menyimpan hasil panen untuk kebutuhan sendiri. Berdasarkan hasil panen rata -rata petani di Kecamatan Polung Kabupaten Humbang Hasundutan. Hasil analisa usahatani padi yang dilakukan petani dengan sistem hambur maupun dengan sistem tanam pindah menunjukkan produksi yang dihasilkan masih kurang dari rata-rata produksi padi nasional 2020 sebesar 5.1 t/ha (BPS,2019).

Tabel4. Analisa Usahatani Padi dengan Tanam Pindah dan Sistem Hambur di Kecamatan Polung Kabupaten Humbang Hasundutan

\begin{tabular}{lcc}
\hline \multicolumn{1}{c}{ Uraian } & Tapin (Rp) & Hambur/tabela (Rp) \\
\hline Pengeluaran: & $\mathbf{1 1 , 9 0 0 , 0 0 0}$ & $\mathbf{1 1 , 5 5 0 , 0 0 0}$ \\
a.Sarana Produksi: & 2.950 .000 & $3,450,000$ \\
b. Upah & $8,950,000$ & $8,100,000$ \\
Penerimaan & $\mathbf{2 3 , 1 0 0 , 0 0 0}$ & $\mathbf{2 1 , 7 2 5 , 0 0 0}$ \\
Produksi & $4,200.00$ & $3,950.00$ \\
Harga & 5,500 & 5,500 \\
Keuntungan & $\mathbf{1 1 , 2 0 0 , 0 0 0}$ & $\mathbf{1 0 , 1 7 5 , 0 0 0}$ \\
R/C & $\mathbf{1 . 9 4}$ & $\mathbf{1 . 8 8}$ \\
\hline
\end{tabular}

Proceedings homepage: $\underline{\text { https://conferenceproceedings.ump.ac.id/index.php/pspfs/issue/view/9 }}$ 
Komponen biaya usahatani yang dikeluarkan berupa pembelian sarana produksi pertanian (benih, pupuk dan pestisida) dan upah tenaga kerja.yang digunakan selama melakukan usahatani meskipun tenaga kerja yang diigunakan adalah tenaga kerja dalam keluarga yang meliputi istri dan anak dan kerabat. Hasil analisa usahatani padi dengan sistim tabur dan hambur memberikan R/C yang hampir sama yaitu tapin $(1,94)$ dan hambur $(1,88)$.

Berdasarkan Tabel 4 menunjukkan bahwa dengan sistim tanam pindah (tapin) biaya pengeluaran lebih besar dibandingkan dengan tanam hambur meskipun penerimaan pada sistem tapin lebih besar dibanding sistem hambur. Namun jika dilihat bahwa nilai R/C kedua cara tanam ini masih menunjukkan nilai yang tidak terlalu jauh berbeda maka kedua sistem ini masih dianggap layak oleh petani untuk digunakan sampai saat ini.

\section{KESIMPULAN}

Lahan usahtatani padi di Kecamatan Polung Kabupaten Humbang Hasundutan memiliki agroekositem sawah dataran tinggi sampai saat ini sebagian besar masih menerapkan pertanaman padi 1 (satu) kali dalam setahun (IP 100). Dengan keterbatasa sumberdaya alam penerapan teknologi padi yang dilakukan petani masih memberikan produktivitas rata-rata untuk sistim tanam pindah (3.9- 4.5 ton/ha ) sedangkan sistim tanam benih langsung dengan hambur (3.7- $4.2 \mathrm{t} / \mathrm{ha}$ ) masih dibawah produktivitas padi rata-rata nasional. Sebesar 5,1 t/ha. Hasil analisa usahatani padi dengan sistim tabur dan hambur memberikan R/C yang hampir sama yaitu tapin $(1,94)$ dan hambur $(1,88)$ sehingga kedua sistim tanam ini masih tetap digunakan oleh perani.

\section{DAFTAR PUSTAKA}

Azmi, M., Chin, D.V, Vongsaroj, P, Johnson, D.E. (2005). Emerging issues in weed management of directseeded rice in Malaysia, Vietnam, and Thailand. In: Toriyama, K., Heong, K.L., Hardy, B. (Eds.), Rice is Life: Scientific Perspectives for the 21st Century. Los Banos, Philippines/Japan, International Rice Research Institute and Tsukuba/Japan International Research Center for Agricultural Sciences, pp. 196198.

Baloch, A.W., Soomro,A.M, Javed M.A, Ahmed M, Bughio H.R. and Bughio M.S. (2002). Optimum plant density for high yield in rice (Oryza sativa L.). Asian J. Plant Sci. 01(02): 114-116.

Bakker RR, Bell MA, Rickman JF (2002). Mechanization issues in tillage and crop establishment for dry directseeded rice. In: Pandey S, Mortimer M, Wade L, Tuong TP, Lopez K, Hardy B (eds) Direct seeding: research issues and opportunities. IRRI, Los Banos, pp 219-230.

Bhushan L, Ladha JK, Gupta RK, Singh S, Tirol-Padre A, Saharawat YS, Gathala M, and Pathak H. (2007). Saving of water and labor in a rice-wheat system with no-tillage and direct seeding technologies. Agron J 99:1288-1296.

Bouman BAM, Humphreys E, Tuong TP, Barker R. (2007). Rice and water. Adv Agron 97: 187-237.

Bozorgi,H.R.,A.Faraji,R.K.Danesh,A.Keshafarz,E.Azarpour And F.Tarighi, (2011). Effect of plant density on yield and yield components of rice. World applied science journal. Vol.12(11):2053-2057.

Chauhan B, Johnson D (2009) Ecological studies on Cyperus difformis, Cyperus iria and Fimbristylis miliacea: three troublesome annual sedge weeds of rice. Ann Appl Biol 155: 103-112.

Chauhan, B.S. and David E. Johnson, (2010). Implications of narrow crop row spacing and delayed Echinochloa colona and Echinochloa crus-galli emergence for weed growth and crop yield loss in aerobic rice. Field Crops Res. 117: 177-182.

Farooq M., Kadambot, Siddique HM, Rehman H, Aziz T, Lee D, Wahid A,(2011). Rice direct seeding: Experiences, challenges and opportunities. Soil Tillage Res 111: 87-98.

Islam,M,R.,M,A.H.Khan,M.S.Rahman,M.S.Alam, and S Arifin, (2012).Effect Of spacing and number of seedlings per hill on the yield performance of fine rice cv.Kaliriza. J.Agrofor.Environ.6(1):79-82.

Maradpour,S.,R.Koohi,M.Babael and M.G.Khorshidi, (2013).Effect of planting date and planting densityon rice yield and growth analysis (Fajr variety). International Journal of agriculture and crop science. Vol.5 (3):267-272.

Pahruddin, A, Maripul dan Rido, P. (2004). Cara Tanam Padi Sistem Legowo Mendukung Usaha Tani di Desa Bojong, Cikembar Sukabumi. Buletin Teknik Pertanian 9 (1).

Pujiasmanto,(2013). Perkuat ketahanan pangan nasional kita. Guru Besar Fakultas Pertanian Universitas Sebelas Maret (UNS). Surakarta. http://www.uns.ac.id. 
Pandey S, Velasco L, (2002). Economics of direct seeding in Asia: patterns of adoption and research priorities. In: Pandey S, Mortimer M, Wade L, Tuong TP, Lopez K, Hardy B (eds) Direct seeding: research issues and opportunities. IRRI, Los Banos, pp 3-14.

Rao, A.N., D.E. Jhonson, B. Sivaprasad, J.K. Ladha and A.M. Mortimer, (2007). Weed management in direct seeded rice. Adv. Agron., 93: 153-255.

Rasool,f.,Habib and M.I.Bhat, (2012). Evaluation of plant spacing and seedlings per hill on rice (Oryza sativa L.,) productivity under temperate conditions, Pak. J.Agric,Sci., 49;169-172.

Rickman JF, Meas P, Som B, Poa S, (2001). Direct seeding of rice in Cambodia. In: Increased lowland rice production in the Mekong region. In: Proceedings of an international workshop, Vientiane, Laos, 30 October-2 November, 2000. Australian Centre for International Agricultural Research, Canberra, pp 60-65.

Sutoro dan A.K. Makarim, (1997). Bentuk tajuk berbagai varietas padi dan hubungannya dengan potensi produksi. Penelitian Pertanian Tanaman Pangan 15:68-78.

Tyeb,A.,S.K.Paul, and M.A.Samad, (2013). Performance of variety and spacing on the yield and yield contributing characters of transplanted Aman rice. Journal Agrofor. Environ. 7(1):57-60.

Weerakoon WMW, Mutunayake MMP, Bandara C, Rao AN, Bhandari DC, Ladha JK (2011). Direct-seeded rice culture in Sri Lanka: Lessons from farmers. Field Crops Res doi:10.1016/j.fcr.2010.11.009 (In press).

Zhao, D.L., Bastiaans, L, Atlin, G.N. and Spiertz, J.H.J. (2007). Interaction of genotype $x$ management on vegetative growth and weed suppression of aerobic rice. Field Crops Research 100, 327-40. 